\title{
Self-perception of body by women of child-bearing age
}

\author{
Marta Makara-Studzińska', Monika Wrotna², Karolina Kryś-Noszczyk', Artur Wdowiak² \\ ${ }^{1}$ Department of Applied Psychology, Medical University, Lublin, Poland \\ 2 Diagnostic Techniques Unit, Faculty of Nursing and Health Sciences, Medical University, Lublin, Poland \\ Makara-Studzińska M, Wrotna M, Kryś-Noszczyk K, Wdowiak A. Self-perception of body by women of child-bearing age. J Pre-Clin Clin Res. \\ 2014; 8(2): 90-94. doi: 10.5604/18982395.1135657
}

\begin{abstract}
Introduction. In psychology, the way in which we perceive our body is what is called "body image", a concept which is associated with our social and psychical functioning. A positive image of one's own body is connected with being attractive, having high self-esteem, high self-confidence and general satisfaction with life [1]. Therefore, contentment, or lack thereof, of one's body comprises an emotional element of body image [2]. The feelings we have towards our body are changing all the time, as well as other behaviours and are conditioned by individual circumstances and mood. Nevertheless, our relationship with the body and its main components are a relatively stable construction [3].

Aim of the study. Recognition of the emotional component of body image of the polled women, and observation of behaviours concomitant with dissatisfaction, lead to improvement of body appearance.

Methods and materials. The study was conducted in 2014, in which 200 women of child-bearing age - students of Medical University in Lublin, Poland, participated. The applied measurement tools were a questionnaire and a scale for assessing one's body, both designed by the authors of the study.

Results. The average age of respondents - 22; BMI - 21.1840. In the general "one's body assessment" scale, the highest mean values were achieved in the subscale of "Aspirations for attaining an ideal figure". There is a statistically significant correlation between the status of relationship, diet, and aspiration for an ideal figure.

Conclusions. Most of the surveyed women were satisfied with their appearance and had a high self-esteem. No statistically significant relations were observed between BMI and the subscales of "General body assessment." The "Cult of Thin" created by the mass media did not influence the subjective perception of one's body.
\end{abstract}

Key words

body image, BMI, status of relationship, state of health

\section{INTRODUCTION}

Body image conditioned by age changes together with the attitude towards one's body and the changes taking place therein. Older adolescents aged 16-20, are burdened with greater uncertainty and self-dissatisfaction. One's image in this group is subject to dynamic, developing changes, which translates into a low level of self-acceptance and self-esteem [4]. Early adolescence is somewhere between $20-30$. The sense of one's own "self" in this group stabilizes and fortifies itself, which increases general self-esteem. Self-esteem, as well as feature of appearance, have little adaptive meaning, although they constitute a factor shaping the relations of the subject with self and the environment [5].

We live in times when the "Cult of Thin" dominates: beautiful, attractive, and thin above all [6]. Beauty is a relative value, its subjective character conditioned by taste, preferences and earlier experiences [7].

In Western culture, where feminism dominates, women have been taught that they are judged by their appearance, and their attractive appearance is supposed to be their greatest asset and thus fulfills social obligations [8]. Dissatisfaction with one's body, being afraid of getting overweight, aspiration for a slim figure, a tendency to misestimate weight and body mass, create the determinants of a women's body image with eating disorders [9].

Address for correspondence: Artur Wdowiak, Diagnostic Techniques Unit, Faculty of Nursing and Health Sciences, Medical University, Lublin, Poland

E-mail: wdowiakartur@gmail.com

Received: 13 October 2014; accepted: 16 October 2014
The development of body image is conditioned by a number of factors: personality, behaviour and cognitive variables, individual experiences of a person and sociocultural influence [10]. In the psychological sciences, the issues of defining and experiencing women's corporeality has been the subject of numerous research projects over the last few years. The most prominent of the research theses is eating disorders [11].

The problem of understanding corporeality with respect to one's "self," perceived as the main element of personality structure, is a frequent subject of research for contemporary theoreticians. However, the ultimate solution to this problem is still impossible to achieve because of the ambiguous definition of the corporeal "self." [12].

Objective. The objective of the presented study is to investigate the emotional component of women's body image, satisfaction or lack thereof, and whether the occurring dissatisfaction is accompanied by behaviours leading to the improvement of appearance.

\section{MATERIALS AND METHOD}

The research was conducted in 2014. 200 women participated in the study, all of whom were students of the Medical University in Lublin, Poland, who were studying the following fields:

- obstetrics, 40 people (20\% of respondents);

- nursing, 40 people (20\%);

- physiotherapy, 21 people $(10.5 \%)$; 
- dentistry, 17 people (8.5\%);

- medicine, 26 people (13\%);

- pharmaceutics, 23 people (11.5\%);

- medical analysis, 10 people (5\%);

- dietetics, 6 people (3\%);

- medical rescue, 7 people (3.5\%);

- public health, 10 people (5\%).

The selection of the group was intentional, with the following criteria: age, gender, certified student status and field of study; age range - 19-26.

The applied measurement tool was a questionnaire and a scale for assessing one's body, both designed by the authors of the study. The scale is composed of 21 statements concerning different aspects of body image, and which has four subscales: - acceptance and satisfaction with one's body (points 1-5);

- one's self-esteem (points 6-8);

- aspiration for attaining an ideal figure (points 9-15);

- attachments to contemporary cultural norms (points 16-21).

A 4-level Likert scale was used:

$1=$ definitely no;

2 = rather no;

$3=$ rather yes;

$4=$ definitely yes.

This scale shows to what extent the women agree with the given statements.

In order to see the body image of a given person, the result for this person has to be calculated in every subscale. The higher the value, the higher the intensity of a given quality.

Variables measured on nominal and ordinal scales were calculated on the basis of their occurrence and with the corresponding percentages. The measures of statistical description used in the analysis of quantitative variables were: arithmetic mean, standard deviation, and minimal and maximal value. In order to verify statistical hypotheses, relevant statistical methods were employed. The chisquared test $\left(\chi^{2}\right)$ was applied to check the occurrence of correlation between the examined qualities. With respect to the correlation occurrence, its degree was calculated with Cramer's V coefficient. Significance level assumed was $\mathrm{p}<0.05$, showing statistically significant differences or correlations. The IBM SPSS Statistics (version 21) software was employed for the statistical analysis and creation of database.

\section{RESULTS}

The mean age of respondents was 22. Among the examined, $51 \%(n=103)$ showed rural area as their place of living, whereas city -49 respondents $(n=97)$. The BMI values closed in the range of 15.5 - 30 with an average BMI value of 21.1840. In accordance with the norms for BMI, the examined women were characterized by the following mean values: $12 \%(n=24)$ - underweight, $81 \%(\mathrm{n}=162)$ - correct body weight, and $7 \%(n=14)$ - overweight. $73 \%(n=146)$ of all respondents replied that their body weight is proper, whereas $27 \%(n=54)$ considered their body weight improper.

$48 \%(n=96)$ of the respondents stated that they are in a relationship, and $46 \%(\mathrm{n}=93)$ that they are not in a relationship; $5.5 \%(n=11)$ are married. Among the respondents, $40.5 \%$ $(n=81)$ stated that they were in a sexual relationship, while $59.5 \%(n=119)$ did maintain a sexual relationship; $3 \%(n=6)$ acknowledged that they had children, whereas $97 \%(\mathrm{n}=194)$ did not have any children.

Only $8.5 \%(n=17)$ of the respondents replied they are on a diet; $91.5 \%(n=183)$ were not on a diet. The study showed that the great majority $-86.7 \%$, were on a diet to improve their physical appearance. The aspiration to be healthy this way was demonstrated by $40 \%$ of the respondents. The majority of the women $(59 \% ; n=118)$ stated that their state of health is good in comparison with their peers, $23 \%(n=46)$ as good, and $15 \%(n=30)$ as satisfactory; $2.5 \%(n=5)$ stated that their state of health poor, and $0.5 \%(n=1)$ as bad.

When asked whether they liked their own body, the majority of the respondents $(62 \% ; n=12)$ replied "rather yes," $10.5 \%(n=21)$ - "definitely yes", $21.5 \%(n=43)$ - "rather no", and $6 \%(n=12)$ that they definitely were not satisfied with their body. $72.5 \%(n=145)$ of the respondents were satisfied with their body, and the majority had a high self-esteem. $31 \%(n=62)$ responded "definitely yes," $58 \%(n=116)$ - "rather yes," whereas $10 \%(n=20)$ that they rather do not have a high self-esteem, and $1 \%(n=2)$ definitely did not have a high self-esteem.

Table 1. Subscales of general scale of body assessment

\begin{tabular}{lcccc}
\hline \multicolumn{1}{c}{ Scale of general self-esteem } & Minimum & Maximum & M & SD \\
\hline $\begin{array}{l}\text { Acceptance and satisfaction } \\
\text { with one's body }\end{array}$ & 5.00 & 20.00 & 12.9350 & 2.84628 \\
\hline High self-esteem & 3.00 & 12.00 & 8.0350 & 1.78316 \\
\hline Aspiration for attaining ideal figure & 10.00 & 27.00 & 18.9900 & 3.15112 \\
\hline $\begin{array}{l}\text { Attachment to contemporary } \\
\text { cultural norms }\end{array}$ & 6.00 & 23.00 & 15.4100 & 3.04108 \\
\hline
\end{tabular}

In the scale of general self-esteem, the highest mean values were attained in the subscale of "Aspiration for attaining ideal figure" ( $M=18.99)$, and in the subscale of "Attachment to contemporary cultural norms" $(M=15.41)$. The greatest number of the respondents showed an average intensity of the qualities in each subscale (Tab. 1).

In the subscale entitled "Acceptance and satisfaction of one's body" (Fig. 1):

- 20.5\% ( $n=41)$ showed minimal intensity of the quality;

- $65.5 \%(n=131)$ showed an average intensity;

- 14\% $(n=28)$ showed maximal intensity.

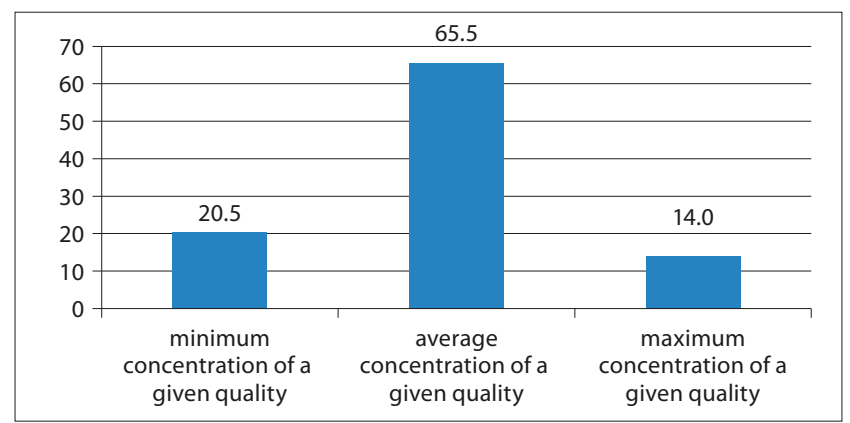

Figure 1. Subscale of "Acceptance and satisfaction of one's body"

The authors observed a statistically significant correlation between the subjective state of one's health and acceptance and satisfaction of one's body. Pearson's chi-squared test was 24.398; $\mathrm{df}=4 ; \mathrm{p}=0.000$. Cramer's V correlation equaled 0.247; 
approximate significance -0.000 . What is important in this correlation is the fact that the women who assessed their body weight as proper attained a higher score on the subscale of "Acceptance and satisfaction of one's body."

Another statistically significant correlation was observed between the subjective sense of the correctness of one's body weight, and acceptance and satisfaction of one's body. Pearson's chi-squared test was calculated at 40.177; $\mathrm{df}=2 ; \mathrm{p}=0.000$. Cramer's V coefficient -0.448 ; approximate significance -0.000 . The importance of this correlation is that women who have the feeling that their body weight is proper achieved better results in the subscale of "acceptance and satisfaction of one's body."

Among the people with a minimal intensity of the "acceptance and satisfaction of one's body" quality, 3.5\% ( $n=7)$ were underweight, $14.5 \%(\mathrm{n}=29)$ had a proper BMI level, and $2.5 \%(n=5)$ were overweight. Among the respondents with an average intensity of quality, $8.5 \%(\mathrm{n}=17)$ were underweight, $54.5 \%(n=109)$ had a proper BMI level, and $2.5 \%(n=5)$ were overweight. The maximal intensity of quality among the underweight was $1 \%(n=2), 11 \%(n=22)$ of respondents had a proper BMI level, and $2 \%(n=4)$ were overweight (Fig. 26). The result of the chi-squared test was 7.748; $\mathrm{df}=4 ; \mathrm{p}=0.113$. Thus, there is no statistically significant correlation between acceptance and satisfaction of one's body and BMI.

In the subscale "High self-esteem" (Fig. 2):

- minimal intensity of quality was characteristic of $16.5 \%$ $(n=33)$ of respondents;

- average intensity of quality $-62.5 \%(n=125)$;

- maximal intensity of quality - $21 \%(n=42)$.

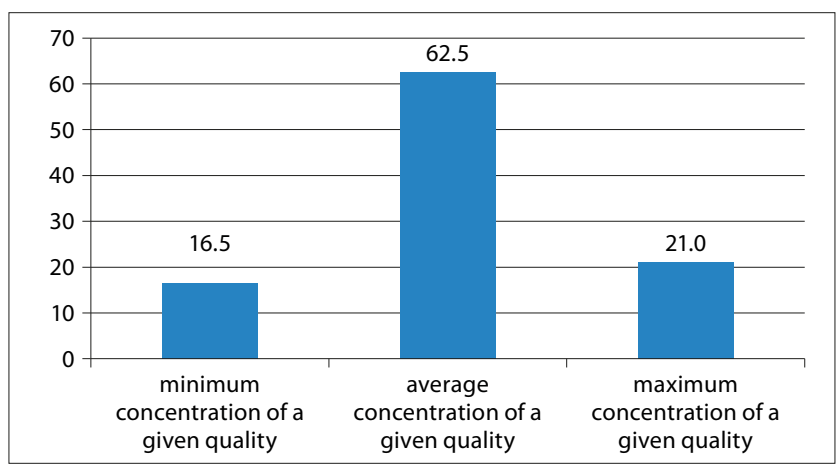

Figure 2. Mean results in the "High self-esteem" subscale

A statistically significant correlation was observed between the subjective assessment of one's health and high selfesteem. Pearson's chi-squared test was 20.611; $\mathrm{df}=4 ; \mathrm{p}=0.000$. Cramer's V coefficient was 0.227 ; approximate significance -0.000 . What is important in this correlation is that the respondents who considered their state of health as very good attained higher results in the "High self-esteem" subscale.

Among respondents with the minimum intensity of the quality in the "High self-esteem" subscale, 2.5\% ( $n=5)$ were underweight, $13.5 \%(\mathrm{n}=27)$ had a proper BMI level, and $0.5 \%$ $(n=1)$ were overweight. In the group of respondents with an average intensity of the quality, $8 \%(n=16)$ were underweight, $52.5 \%(n=105)$ had a proper BMI level, and $2.5 \%(n=5)$ were overweight. Among the women with maximum intensity of the quality, 2.5\% $(n=5)$ were overweight, $14.5 \%(n=29)$ had a proper BMI level, and $4 \%(n=8)$ were overweight (Fig. 3). The chi-squared test was $12.022 ; \mathrm{df}=4 ; \mathrm{p}=0.017$. This result shows that there is no correlation between high self-esteem and BMI.
In the subscale "Aspirations for attaining ideal figure" (Fig. 3):

- minimal intensity of quality was characteristic of $7 \%$ $(n=14)$ respondents;

- average intensity of quality - $63 \%(n=126)$;

- maximum intensity of quality - 30\% $(n=60)$.

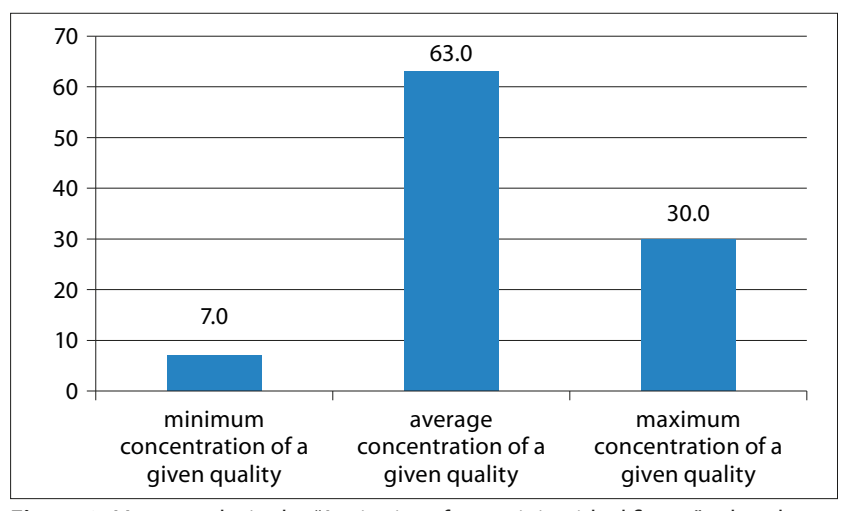

Figure 3. Mean results in the "Aspirations for attaining ideal figure" subscale

There was a statistically significant correlation between the relationship and aspiration for attaining an ideal figure. Pearson's chi-squared test in this case was 10.634; $\mathrm{df}=4 ; \mathrm{p}=0.031$. Cramer's V coefficient -0.163 ; approximate significance -0.031 . What is important here is that the women in a relationship scored higher in the "aspirations for attaining ideal figure" subscale than women without a partner.

There is a statistically significant correlation between diet and aspiration for attaining an ideal figure. Pearson's chisquared test was $14.830 ; \mathrm{df}=2 ; \mathrm{p}=0.001$. Cramer's $\mathrm{V}$ coefficient - 0.272; approximate significance -0.001 . The important thing about this correlation is the fact that the respondents on a diet scored higher in the "aspiration for attaining ideal figure" subscale.

Among the respondents with minimum intensity of quality in the "aspiration for attaining an ideal figure" subscale, $1 \%$ $(n=2)$ were underweight, $9.5 \%(n=19)$ had a proper BMI level, and $1 \%(n=2)$ were overweight. In the group with average intensity of quality, 9.5\% $(n=19)$ of the respondents were underweight, $50 \%(n=100)$ had a proper BMI level, and 3.5\% $(n=7)$ were overweight. In the case of women with maximum intensity of quality, $2.5 \%(n=5)$ were underweight, $25 \%(n=50)$ had a proper BMI level, and $2.5 \%(n=5)$ were overweight (Fig. 4). The chi-squared test result was 3.250; $d f=4 ; p=0.517$, which showed no correlation between BMI and aspiration for attaining ideal figure.

In the "Attachment to contemporary cultural norms" subscale (Fig. 4):

- minimum intensity of quality was characteristic of $16 \%$ $(n=32)$ of the polled women;

- average intensity of quality - 57\% $(n=114)$;

- maximum intensity of quality - $27 \%(n=54)$.

Among the respondents there was a negative attitude towards aspiring for the slim body proposed by the media. $36.5 \%(n=73)$ of women definitely did not follow this trend, $41 \%(n=82)$ - rather no in comparison to $19 \%(n=38)$ who stated that they followed this to some extent ("rather yes" option) and 3.5\% (n=7) - "definitely yes".

Among the respondents, $37.5 \%(n=75)$ stated "definitely yes" when asked whether appearance is crucial for other 


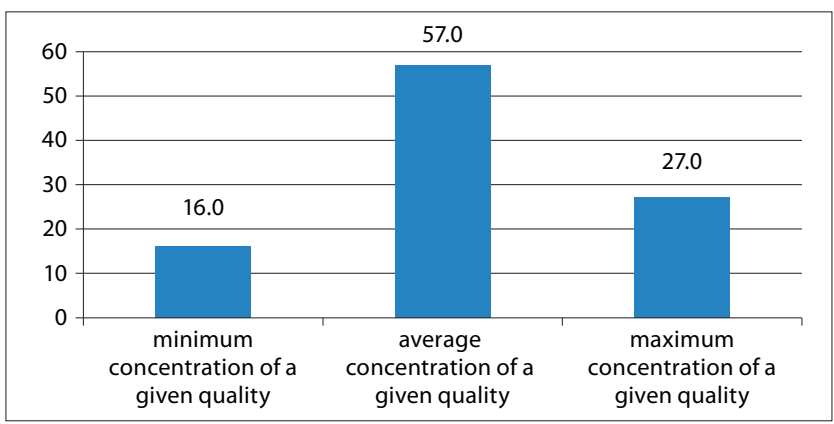

Figure 4. Mean results in the "Attachment to contemporary cultural norms" subscale

people's perception. To the same question, $51.5 \%$ answered "rather yes," $10.5 \%(\mathrm{n}=21)$ - "rather no" and only $0.5 \%(\mathrm{n}=1)$ - "definitely no."

\section{DISCUSSION}

On the basis of the conducted analysis, it can be deduced that the majority of women are satisfied with their physical appearance. Additionally, they are characterized by high self-esteem, which translates into their being in a good relationship with their peers. They do not, however, follow the model of body image presented by mass media.

There are a number of ways of measuring body image. The (sub)scales used for this are: dedicated to behavioural components of body image, emotions in experiencing the body (fear, shame, satisfaction) and the cognitive component of image, i.e. intensity on figure and proportions [13].

The above results cannot be directly compared to the results achieved by other researchers, chiefly due to the age of the respondents, as well as dissimilarities in the tools applied..

In the research by M. Lipowska and M. Lipowski, secondary school students and first-year undergraduates were polled (aged 18-23), for whom "the body esteem scale" by S. Franzoi and S. Shields was used for assessment. The scale comprised 35 statements in 3 subscales, separately for men and women, and is used to determine the body image of the respondents. For women, the test uses the following subscales: weight control, physical fitness and sexual attraction. The aim of the research was to show the extent of the optimism of the respondents, their body image in adolescence, remaining under the influence of factors which contribute to this image. The mean BMI was 21.2. The research also showed that sexual attraction was the main factor which contributed to the respondents self-attraction; they would like to be slimmer than their partner's expectation, and breast size was considered the main indicator of sexual attraction. Furthermore, the research demonstrated that high body mass is the greatest reason for self-dissatisfaction, although optimism among the respondents was high [3]. Surprisingly, in the presented study, the BMI value was shown to be identical to that obtained during the research phase. However, there was no similarity between satisfaction with one's appearance and BMI, because in the conducted research no statistically significant correlations were observed between the "scale of general self-esteem" subscales and BMI.

In the research of B. Izydorczyk and A. Rybicka-Klimczyk, the aim of which was recognition of the psychological body image in a group of 79 secondary school students (Fig. 1) and undergraduates (Fig. 2). In the research, the CDRS test (Contour Drawing Rating Scale) was implemented in which 9 figures were presented, ordered from slim to obese. The respondents were to indicate their own figure at present, the ideal figure and the one desired. The EDI test (Eating Disorder Inventory) by Garner, Olmsted and Poliva was also used. This test is characterized by 64 statements comprising 8 subscales: aspiration for maintaining a slim figure, dissatisfaction with one's body, bulimia, perfectionism, ineffectiveness, distrust in personal relationships, fear of maturity and interoceptive awareness. Another test implemented in the study was the PASTAS test (Physical Appearance State and Trait Anxiety Scale), according to K. Thomson, where the respondents determined the level of fear with reference to 16 body parts using a 5 -grade Likert scale. The mean BMI of group I was 19.04, whereas group II - 20.98. The results showed that women from group II were more aware of their appearance than women from group I. Female adolescents also demonstrated a greater disparity between "real self" and "ideal self" in comparison to group II. Respondents from group II, on the other hand, expressed a more fearful attitude towards their body in relation to their younger peers [14].

The research by A. Zarek was aimed at determining from what aspect (process or object) the respondents categorized elements of their body image. 177 people, aged 19-53, were surveyed, and the measurement tool used was the "Body image questionnaire," based on the Body Cathexis Scale by P. F. Secord and S. J. Jourard. Questionnaire I was composed of 54 body elements, in which the surveyed person was to assign an element to one of the three categories: bodily functions (F), body parts (C) and other (I); questionnaire II was employed to determine the level of satisfaction of each of the elements on a 5-grade scale, and questionnaire III was used to discover how important individual elements are for the respondents. The frequency of assignments to particular categories was calculated. Afterwards, on the basis of components in each category, the mean value of the global index was determined.

\section{CONCLUSIONS}

The general conclusion drawn from the study is that the level of subjective satisfaction is associated with the assessment of body element with respect to appearance or action. However, of less significance is the fact of recognizing the level of satisfaction as a function or a body part [1]. It can also be stated that the results of the research reflect the results attained by other authors regarding satisfaction with one's body and high self-esteem by women aged 19-26.

Therefore, the following conclusions can be drawn:

1) The majority of women is satisfied with their physical appearance.

2) No statistically significant correlations were observed between BMI and the subscales of the general self-esteem scale.

3) The majority of respondents is characterized by high selfesteem.

4) Respondentss' dissatisfaction with appearance does not have a bearing on the aspiration for having an ideal figure and improving one's appeal.

5) The "cult of thin" created by mass media does not affect the subjective assessment of body mass. 
6) Being in a relationship and diet are the two most frequent factors contributing to the achievement of better results in the "aspiration for attaining ideal figure" subscale.

Interest in the issue of body image in the presented study has its justification based on the increasing dissatisfaction with appearance, and the increasing number of eating disorder cases. Future research into this phenomenon should be based on a wider context, not only aesthetic.

\section{REFERENCES}

1.Zarek A. Obraz ciała w ujęciu procesu lub obiektu a satysfakcja $z$ własnego ciała [Body image viewed as an object or process and body satisfaction]. Roczniki Pomorskiej Akademii Medycznej w Szczecinie 2009; 55(1): 100-106 (in Polish).

2.Brytek-Matera A, Charzyńska E. Związek pomiędzy emocjonalnym aspektem obrazu ciała a ekspresja uczuć u kobiet z otyłością [Relationship between emotional aspect of body image and expression of feelings in obese women]. Endokrynologia, Otyłość i Zaburzenia Przemiany Materii 2009; 5(4): 198-205 (in Polish).

3.Lipowska M, Lipowski M. Poziom optymizmu a akceptacja własnego ciała przez kobiety w okresie adolescencji [Level of optimism and acceptance of own body by women during the period of adolescence]. Psychologia rozwojowa 2006; 11(3): 89-96 (in Polish).

4. Kędzierska B, Znajmiecka-Sikora M. Młodzież jako kreator własnego zdrowia - struktura obrazu siebie w okresie późnej adolescencji a postawy wobec własnego zdrowia [Adolescents as creators of own health - structure of self-image in late adolescence and attitudes towards own health]. Sztuka leczenia 2004; 10(2): 31-37 (in Polish).

5. Fenczyn J, Woźniak MA. Akceptacja własnego ciała przez osoby w wieku 15-16 i 23-24 lat [Acceptance of own body by individuals aged 15-16 and 23-24]. Psychiatria i Psychologia Kliniczna 2004; 4(1): 20-33 (in Polish).
6. Brytek-Matera A, Charzyńska E. Związek pomiędzy emocjonalnym aspektem obrazu ciała a ekspresja uczuć u kobiet z otyłością [Relationship between emotional aspect of own body image and expression of feelings in obese women]. Endokrynologia, Otyłość i Zaburzenia Przemiany Materii 2009; 5(4): 198-205 (in Polish).

7. Drozdowski P. Spojrzenie na piękno ciała kobiety [A view on beauty of a woman's body]. Ginekologia Praktyczna 2008; 16(3): 35-41 (in Polish).

8. Schier K. Obraz ciała - kontekst kulturowy. in: Piękne brzydactwo: psychologiczna problematyka obrazu ciała i jego zaburzeń [Body image - cultural context. In: A beautiful ugly thing: a scope of psychological problems concerning body image and its disorders]. Warszawa: Wydawnictwo Naukowe Scholar, 2009.p.50-59 (in Polish).

9. Brytek-Matera A. Wizerunek ciała. in: Brytek-Matera A. Wizerunek ciała w anoreksji i bulimii psychicznej [Brytek- Matera A. Body image in anorexia and bulimia psychological disorder]. Warszawa: Wydawnictwo Difin, 2009: 11-43 (in Polish).

10. Izydorczyk B, Rybicka-Klimczyk A. Środki masowego przekazu i ich rola w kształtowaniu wizerunku ciała u zróżnicowanych wiekiem życia kobiet polskich (analiza badań własnych) [Mass media and their role in shaping body image in Polish women at various ages (analysis of own studies)]. Problemy medycyny rodzinnej 2009; 11(3): 20-32 (in Polish).

11. Bieńkowska N, Izydorczyk B. Obraz Ja cielesnego - wybrane teoretyczne wątki rozumienia psychologicznych mechanizmów zjawiska. Część I [Body self image - selected theoretical plots in understanding psychological mechanisms of the phenomenon. Part 1]. Problemy medycyny rodzinnej 2008; 10(4): 52-58 (in Polish).

12. Sakson-Obada O. Rozwój ja cielesnego w kontekście wczesnej relacji z opiekunem [Development of body self in the context of early relation with caregiver]. Roczniki Psychologiczne 2008; 11(2): 27-44 (in Polish).

13. Kulbat J, Głębocka A. Pomiar wizerunku ciała: przegląd technik i procedur badawczych [Measurement of body image: review of research techniques and procedures]. In: Głębocka A, Kulbat J (eds). Wizerunek ciała. Portret Polek. Wyd. UO, Opole 2005, 29-44 (in Polish).

14. Izydorczyk B, Rybicka-Klimczyk A. Diagnoza psychologiczna poznawczych i emocjonalnych aspektów obrazu ciała u dziewcząt i młodych kobiet polskich [Psychological diagnosis of cognitive and emotional aspects of body image among Polish girls and young women]. Problemy medycyny rodzinnej 2008; 10(4): 24-35 (in Polish). 